\title{
A novel tetrahydrotetramethylbenzophenanthridinone derivative inhibits ATL cell proliferation
}

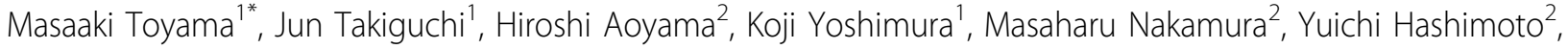 \\ Masanori Baba'
}

From 16th International Conference on Human Retroviruses: HTLV and Related Viruses

Montreal, Canada. 26-30 June 2013

We have previously reported that the tetrahydrotetramethylnaphthalene (TMN) derivative TMNAA is a selective inhibitor of Adult T-cell Leukemia (ATL) and HTLV-1-infected cell lines but not non-ATL cell lines and peripheral blood mononuclear cells (PBMCs). In this study, several derivatives of TMNAA were synthesized and examined for their inhibitory effect on the proliferation of various $T$ cell lines and PBMCs by a tetrazolium dye method. The modes of cell death and cell cycle arrest were also examined by flow cytometry. Among the compounds, MN417 having a tetrahydrotetramethylbenzophenanthridinone structure was found to be a more potent inhibitor of ATL and HTLV-1infected cell lines than TMNAA. The 50\% inhibitory concentrations (IC50s) of MN417 and TMNAA for ATL and HTLV-1-infected cell lines, including S1T and MT-2 cells, were 0.59-6.6 and 2.2-34.2 $\mu \mathrm{M}$, respectively, depending on the test cell lines. In contrast, the IC50s of MN417 and TMNAA for non-ATL cell lines, such as MOLT -4 and CEM cells, were $>20$ and $>100 \mu \mathrm{M}$, respectively. The elimination of the TMN moiety from MN417 failed to inhibit the proliferation of ATL and HTLV-1-infected cell lines, suggesting that the TMN moiety was required for the selective inhibition of these cell lines. Furthermore, both MN417 and TMNAA hardly induced apoptosis and cell cycle arrest. Thus, although the target molecule for inhibition of ATL cells remains to be elucidated, the compounds may have potential as novel and selective chemotherapeutic agents ATL.

* Correspondence: toyama@m2.kufm.kagoshima-u.ac.jp

'Center for chronic viral diseases, Kagoshima University, Kagoshima, Japan Full list of author information is available at the end of the article

\section{Authors' details}

${ }^{1}$ Center for chronic viral diseases, Kagoshima University, Kagoshima, Japan. ${ }^{2}$ Institute of Molecular and cellular Biosciences, The University of Tokyo,

Tokyo, Japan.

Published: 7 January 2014

doi:10.1186/1742-4690-11-S1-P82

Cite this article as: Toyama et al: A novel

tetrahydrotetramethylbenzophenanthridinone derivative inhibits ATL cell proliferation. Retrovirology 2014 11(Suppl 1):P82.
Submit your next manuscript to BioMed Central and take full advantage of:

- Convenient online submission

- Thorough peer review

- No space constraints or color figure charges

- Immediate publication on acceptance

- Inclusion in PubMed, CAS, Scopus and Google Scholar

- Research which is freely available for redistribution

Submit your manuscript at www.biomedcentral.com/submit
() Biomed Central 